\title{
Burkitt's lymphoma masquerading as appendicitis - two case reports and review of the literature
}

\author{
Elroy P Weledji ${ }^{1 *}$, Marcelin N Ngowe ${ }^{1}$ and John S Abba ${ }^{2}$
}

\begin{abstract}
Two cases of Burkitt's lymphoma masquerading as appendicitis are reported herein. The diagnoses were made post-operatively from the appendix specimen in one case and from an ileocecal resection specimen for cecal fistula complicating an appendicectomy in the second case. These cases highlight the importance of routine histological examination of appendicectomy specimens.
\end{abstract}

Keywords: Appendicitis, Burkitt's lymphoma, Histology, Treatment

\section{Background}

Burkitt's lymphoma is an unusual variant (5\%) of malignant (B-cell) non-Hodgkin's lymphoma, which was first described between 1958 and 1962 in children in subSaharan Africa [1]. Over half of these patients presented with jaw tumours, but it was soon realised that other organs, including distal ileum, caecum, ovaries, kidney, or the breast, were often involved and that the initial presentations were variable. Non-Hodgkin's lymphoma is the most common malignant tumour of the bowel in children older than 5 years but Burkitt's lymphoma presenting as appendicitis is rare [2]. Untreated cases run a rapid downhill course and die with wide-spread metastases to the liver, kidneys, and other organs [3].

The epidemiological and laboratory findings suggest that that the combination of recurrent $P$. falciparum malaria and Epstein-Barr virus (EBV) infection very early in childhood cause B cell hyperplasia which is an essential component of lymphomagenesis [4,5]. A sporadic form of Burkitt's lymphoma occurs elsewhere in the world and has only a 5 to $15 \%$ degree of association with EBV. A third form, human immunodeficiency virus (HIV)associated Burkitt's lymphoma is associated with EBV in approximately $40 \%$ of cases $[4,6]$. If suspicious of intraabdominal Burkitt's lymphoma especially in an endemic area, pre-operative imaging with ultrasonography in expert hands or computed tomography $(\mathrm{CT})$ is effective at

\footnotetext{
* Correspondence: elroypat@yahoo.co.uk

'Department of Surgery, Faculty of Health Sciences, University of Buea, P.O. Box 12, Buea, S.W. Region, Cameroon

Full list of author information is available at the end of the article
}

diagnosing the malignant nature of the tumour $[7,8]$. Histological examination of the appendix specimen following appendicectomy for an apparent appendicitis is mandatory as it may disclose an ileocecal Burkitt's lymphoma.

\section{Case presentation}

\section{Case 1 presentation}

A 13-year-old female was admitted electively for investigation of a long history (3 years) of right iliac fossa pain. This was a recurring dull and aching pain that had not responded to analgesia and antibiotics for suspected relapsing or 'chronic' appendicitis. She had no anorexia or weight loss. She had no constitutional symptoms, such as lethargy, fever, or night sweats, and had no altered bowel habits or urinary symptoms. On examination she appeared clinically well. The abdomen was soft but tender on deep palpation of the right iliac fossa. Thefull blood count and urinalysis were normal. Ultrasound examination suggested an appendicitis. At operation, a Lanz incision was made in the right iliac fossa. There was some free fluid in the peritoneal cavity but the appendix did not appear inflamed. It simply had a yellowish tinge. There was terminal ileal lymphadenopathy. The histology of the appendix specimen revealed a B-cell non-Hodgkin's lymphoma consistent with Burkitt's lymphoma (Figure 1). She made full postoperative recovery and underwent a 6month course of chemotherapy (i/v cyclophosphamide and vincristine together with oral prednisolone) having tested as HIV seronegative prior to its commencement. Eight years later, she is very well and has graduated as an accountant. 


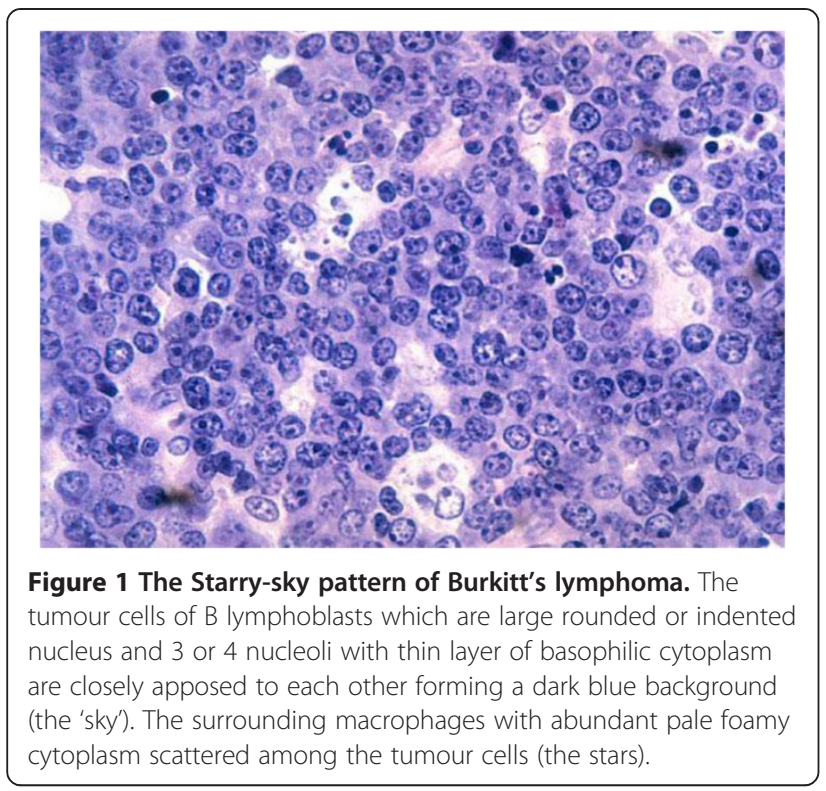

\section{Case 2 presentation}

An 18-year-old female was referred as an emergency with a cecal fistula complicating an appendicectomy performedtwo weeks previously. The indication for the appendicectomy was for an apparent appendicitis following a vague history of right iliac fossa pain. An attempted closure of the fistula failed. On examination, she was clinically dehydrated and exhausted but not toxic. She had no constitutional symptoms and the vital signs were normal. There was a persistent and high output (greater than $1 \mathrm{~L} / 24 \mathrm{~h}$ ) intestinal fistula in the right iliac fossa consistent with a cecal fistula. She was resuscitated with appropriate fluids and because of the persistent output from the high-pressure caecum a decision was made for surgical correction two days later. At laparotomy, there was a cecal fistula from the dehisced appendix stump. Apart for significant ileocecal lymphadenopathy the rest of the abdomen appeared normal. Following extensive lavage of the operation field with saline solution, an ileocecal resection with end-to-end anastomosis of the ileum and ascending colon was performed. The histology of the operative specimen confirmed a B-cell non-Hodgkin's lymphoma consistent with Burkitt's lymphoma. She had a stormy post-operative recovery and when fully recovered underwent a 6-month course of chemotherapy (i/v cyclophosphamide and vincristine together with oral prednisolone) having tested as HIV seronegative prior to its commencement. Nine years later she is well with no evidence of metastases but with fertility problems.

\section{Discussion}

Burkitt's lymphoma is a highly aggressive B-cell nonHodgkin's lymphoma and is the fastest growing human tumour $[9,10]$. This EBV-associated lymphoma was one of the first tumours shown to have a chromosomal translocation (chromosome 14) that activates an oncogene (c-MYC) [4]. The incidence is very high with an aggressive clinical course in immunosuppressed patients in nonendemic areas especially when associated with HIV infection. They were all positive for EBV in a case series [11]. Clinically, Burkitt's lymphoma patients do not usually exhibit the B-symptoms (fever, night sweats, and weight loss) characteristic of early non-Hodgkin's lymphoma. This is because the transformation of these cells compromises host defence and evolves mechanisms to escape immune surveillance [12]. Patients with a rapidly growing extranodal intra-abdominal Burkitt's tumour present with symptoms of bowel obstruction, intussusception, or appendicitis [13]. Both cases reported here gave an atypical history for appendicitis especially regarding the duration of the abdominal pain [14]. The differential diagnosis would include a true relapsing or chronic appendicitis which are rare and often difficult to diagnose as the symptoms may be atypical and short-lived [15]. Because of resource limitations, the diagnoses of Burkitt's lymphoma in these cases were post-operative. In the first case the diagnosis was made from the histological examination of the appendix specimen. In the second case, where an ileocecal Burkitt's lymphoma masqueraded as an appendicitis, the diagnosis was made only following the histological examination of the resected ileocecal specimen. The demonstration of a malignant appendix by preoperative imaging with ultrasonography or CT would influence the surgical approach for pathological staging of the disease [16]. A bone marrow biopsy may show infiltration by Burkitt's lymphoma (dissemination) [17]. The diagnosis may also be established by laparoscopy following which the appendix can be removed [18]. Due to Burkitt's lymphoma's rapid doubling time, aggressive chemotherapy is required to control its spread and growth $[19,20]$. Paradoxically it is the high grade non-Hodgkin's lymphoma that may be curable and consequently should be treated with high-dose multidrug regimens in addition to malaria prophylaxis in Burkitt's lymphoma [20]. Intensive chemotherapy with CODOX-M/IVAC (cyclophosphamide, vincristine, doxorubicin, and high dose methotrexate, alternating with ifosfamide, etoposide, and cytarabine) is the definitive treatment $[17,19,20]$. The improved chemotherapy and support care available are due to the better understanding of the biology of the disease $[12,17]$. The outcome has improved and is now excellent in children; the current 5-year survival for advanced (disseminated) Burkitt's lymphoma in children and adolescents has increased by 2 - to3-fold in the past 3 decades to $85 \%$ to $90 \%$ following less than 6 months of intensive chemotherapy $[9,10]$.

The two patients in the case report were tested as being HIV seronegative prior to commencing the above 
standard chemotherapy regimen. The successful outcome in these patients may perhaps not have been achieved if they were HIV seropositive in terms of disease progression and response to chemotherapy [11,21]. Adjuvant $\mathrm{CD} 20$-directed monoclonal antibody therapy with rituximab shows promise for improving outcome and reducing the toxic effects of cytotoxic chemotherapy. Rituximab decreased the recurrence rate and showed a trend in favour of improvement in overall survival or disease-free survival [22]. CODOX-M/IVAC with rituximab is a highly effective regime for the treatment of adult Burkitt's lymphoma which usually has a poor prognosis [23]. Current risk factors in the prognosis of children and adolescent Burkitt's are elevated lactate dehydrogenase greater than twice the upper limit, bone marrow and central nervous system involvement, poor response to cytoreduction therapy, and poor risk cytogenetics $[3,9,10]$. Radiotherapy is used only in emergencies such as superior vena cava syndrome, acute neurological impairment, or in patients with relapse $[1,3,9,10]$. Further investigations including $\mathrm{CT}$ and PET scanning for response evaluation in these patients would be possible in a resourced area. There is a need for more clinical data on the use of PET and magnetic resonance technology in the determination of response evaluation of children with Burkitt's lymphoma $[3,16]$.

\section{Conclusions}

Although Burkitt's lymphoma presenting as appendicitis is rare, it should be considered an important differential diagnosis in children and adolescents from sub-Saharan Africa with atypical right iliac fossa pain. The reported cases demonstrate the importance of histologically examining appendicectomy specimens especially in patients with atypical presentations of appendicitis. The appendix, being a lymphoid organ, may be the most appropriate and accessible extranodal tissue for diagnosing intraabdominal Burkitt's lymphoma or other diseases. Understanding the underlying biology of Burkitt's lymphoma would lead to strategies for prevention and approaches to reduce acute and chronic toxicities from current cytotoxic treatment.

\section{Consent}

A written informed consent was obtained from the patient for publication of this case report and any accompanying images. A copy of the written consent is available for review by the editor-in-chief of the journal.

\section{Consent (Child)}

A written informed consent was obtained from the patient's parent for the publication of this report and any accompanying images.

\begin{abstract}
Abbreviations
CT: Computed tomography; EBV: Epstein-Barr virus; HIV: Human immunodeficiency virus; PET: Posittron emission tomography; MRI: Magnetic resonance imaging.
\end{abstract}

\section{Competing interests}

The authors declare that they have no competing interest.

\section{Authors' contribution}

EPW is the main author and drafted the manuscript. MNN gave advice on the tropical perspective and helped with the literature search. JSA helped with the literature search. All authors read and approved the final manuscript.

\section{Author details}

${ }^{1}$ Department of Surgery, Faculty of Health Sciences, University of Buea, P.O. Box 12, Buea, S.W. Region, Cameroon. ${ }^{2}$ Tiko Cottage Hospitals, Cameroon Development Corporation, Tiko, S.W. Region, Cameroon.

Received: 28 November 2013 Accepted: 12 June 2014

Published: 18 June 2014

\section{References}

1. Burkitt D: A sarcoma involving the jaws in African children. Br J Surg 1958, 46:218-223.

2. Bhardwaj N, Bains SK, Ortrowsky G, Murphy P: A case of Burkitt's lymphoma presenting as suspected appendicitis. Afr J Paed Surg 2010, 7(3):214-215.

3. Bethel CA, Bhathacharyya N, Hutchimson C, Poyman F, Cooney DR: Alimentary tract malignancies in children. J Pediatric Surg 1997, 32:1004-1008. Discussion 1008-1009.

4. Brady G, MacArthur GJ, Farrel PJ: Epstein-Barr virus and Burkitt lymphoma. J Clin Path 2007, 60(12):1397-1402.

5. Mulima N, Molyneux E, Jaffe H, Kamiza S, Borgstein E, Mkandawire N, Liomba G, Batumba M, Lagos D, Gratrix F, Boshoff C, Casabonne D, Carpenter LM, Newton R: Associations between Burkitt lymphoma among children in Malawi and infection with HIV, EBV and malaria: results from a case-control study. PLOS One 2008, 3e:2505.

6. Borukamm GW: Epstein Barr virus and the pathogenesis of Burkitt's lymphoma: more questions than answers. Int J Cancer 2009, 124:1245-1255.

7. Bissen L, Brassen K, Azagra JS, Deirie P: Burkitt's lymphoma of the appendix. JBR-BTR 2002, 85:257-259.

8. Biswas S: Report of a case of abdominal Burkitt's lymphoma presenting as a localised right iliac fossa pain mimicking acute appendicitis. Internet J Surgery 2007, 9:1.

9. De Leval L, Hasserjan RP: Diffuse large B-cell lymphomas and Burkitt lymphoma. Hematol Oncol Clin North Am 2009, 23:791-827.

10. Klein E, Klein G: Burkitt Lymphoma. Semin Cancer Biol 2009, 19:345-346.

11. Dong HY, Scadden DT, de Lavel L, Tang J, Isaacson PG, Harris NL: Plasmablastic lymphoma in HIV-posiive patients: an aggressive Epstein- Barr virus-associated extramedullary plasmacytic neoplasm. Am J Surgical Pathol 2005, 12:1633-1641.

12. God JM, Hague A: Immune evasion by B-cell lymphoma. J Clin Cell Immunol 2011, 2:e103.

13. Wang SM, Huang FC, Wu CH, Ko SF, Lee SY, Hsica CC: lleocaecal Burkitt's lymphoma presenting as ileocolic intussusception with appendiceal invagination and acute appendicitis. J Formos Med Assoc 2010, 109:476-479.

14. Weledji EP, Ngowe NM: The acute abdomen revisited. Afr J Integ Health 2013, 1:1-5.

15. Krukowski ZH: Appendicitis. Surgery 1990, 3:2044-2048.

16. Schaefer EA, Dranone JE, Gupta SK: Clinical challenges and images in gastrointestinal ileocolic intussusceptions caused by Burkitt's lymphoma. Gastrenterology 2008, 134(20):373.

17. Aldoss IT, Wesenburger DD, Fu K, Chan WC, Vose JM, Bierman PJ, Bociek RG, Armitage JO: Adult Burkitt lymphoma: advances in diagnosis and treatment. Oncology (Williston Park) 2008, 22:1508-1517.

18. Paterson Brown S, Eckesley JRT: Laparoscopy as an adjunct to decisionmaking in the acute abdomen. Br J Surg 1986, 73:1022-1024. 
19. Lacasce A, Howard O, Li S, Fisher D, Weng A, Neuberg D, Shipp M: Modified magrath regimens for adults with Burkitt and Burkitt-like lymphomas: preserved efficiency with decreased toxicity. Leuk Lymphoma 2004, 45:761-767.

20. Di Nicola M, Carlo-Stella C, Mariotti J, Devizzi L, Massimino M, Cabras A, Magni M, Matteucci P, Guidetti A, Gandola L, Gianni AM: High response rate and manageable toxicity with an intensive short-term chemotherapy programme for Burkitt's lymphoma in adults. Br J Haematol 2004, 126:815-820.

21. Noy A: Controversies in the treatment of Burkitt lymphoma in AIDS. Curr Opin Oncol 2010, 22:443-448.

22. Wildes TM, Farrington C, Young C, Harrington AM, Foyil KV, Liu J, Kreisel F, Bartlett NL, Fenske TS: Rituximab is associated with improved survival in Burkitt's lymphoma: retrospective analysis from two US academic medical centres. Ther Adv Haematol 2014, 5(1):3-12.

23. Barnes JA, Lacasce AS, Feng Y, Tooney CE, Newberg D, Michaelson JS, Hochberg EP, Abramson JS: Evaluation of the addition of rituximab to CODOX-M/IVAC for 'Burkitt's lymphoma: a retrospective analysis. Ann Oncol 2011, 22(8):1859-1864.

doi:10.1186/1477-7819-12-187

Cite this article as: Weledji et al:: Burkitt's lymphoma masquerading as appendicitis - two case reports and review of the literature. World Journal of Surgical Oncology 2014 12:187.

\section{Submit your next manuscript to BioMed Central and take full advantage of:}

- Convenient online submission

- Thorough peer review

- No space constraints or color figure charges

- Immediate publication on acceptance

- Inclusion in PubMed, CAS, Scopus and Google Scholar

- Research which is freely available for redistribution 